\title{
African theology and African Christology: Difficulty and complexity in contemporary definitions and methodological frameworks
}

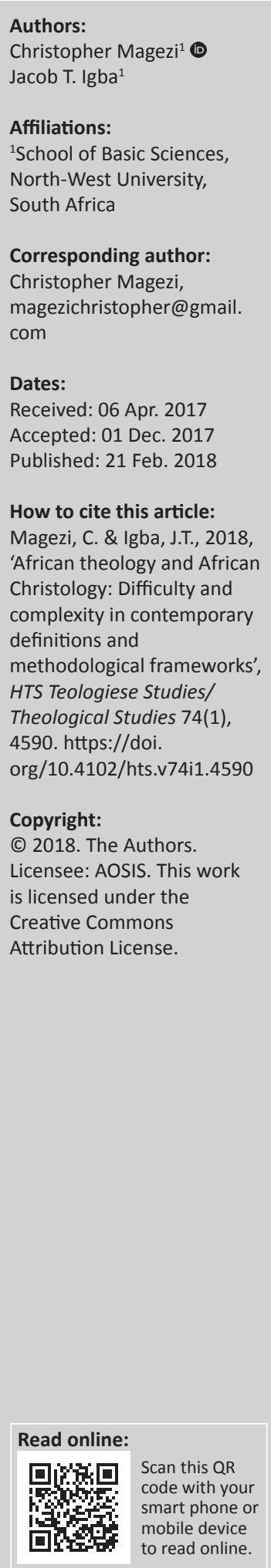

There is an ongoing challenge in defining African theology because of two important reasons: (1) the quest for a definitive African theology is a fairly recent pursuit and (2) the vastness and diversity of the African continent. Given this, this article presents the complexity of defining African theology and its methodological approaches through a background sketch of the development of African theology. Regardless of many definitions of African theology and its purposes, the article acknowledges African Christian theology as theology that should be derived from the interplay between Scripture, Christian tradition and African cosmology. In deriving theology from the aforementioned aspects, African theology should also seek to develop contextual African theologies with global relevance. In this way, African theology can claim its space in the universal church. Although we are conscious of the values and challenges associated with the task of doing African theology, we argue for its necessity. We further argue that if the centrality of Scripture is maintained in the African theological endeavour, it will cause African theologies to have some shared reference point with other Christian theologies and hence engaging globally, while contributing unique African perspectives to global theological discourse.

\section{Introduction}

There is a considerable amount of research (i.e. Mashau \& Fredricks 2008; McGlory 2016; Tiénou 1990; West 2008) which depicts the difficulty and complexity of the task of describing, defining and accurately assessing African theology. This arises from the fact that the quest for a definitive African theology is a fairly recent pursuit, as well as the vastness and diversity of the African continent. ${ }^{1}$ Notably, West (2008) explores key elements found in African Biblical hermeneutics. He places emphasis on the place of the 'real flesh and blood African reader' towards appropriating the text. The relevance of the task of African theology and hermeneutics beyond the reader and the continent was not in the purview of his contemplation. Speckman (2016) shows concerns for the need for such widening relevance. He emphasises African identity and frameworks as central, but maintains that African Biblical hermeneutics has moved from a state of liminality into a cul-de-sac. He proposes a 'celebration of life framework' as the way forward. He elaborates his proposal as based on the teaching of indigenous churches and the traditional (amaqaba) people. Both West and McGlory consign scripture to the margins of the African theological endeavour.

Beyond the authors above, this article presents the difficulties and complexity in contemporary definitions and methodological frameworks of African theology and links the discussion to African Christology, as an example of a key subset within African theology. The first section sketches the background and development of African theology, as well as providing the definitions and differentiations of African theology. At this juncture, the context and task of African theology will also be established. The second section discusses African Christology as the predominant subset and an example of doing African theology. Here, the methodological approaches in African theology and African Christology are discussed with the view to establish the underlying challenges in doing African theology. Once this is done, the article concludes by drawing attention to the centrality of Scripture in the African Christian theological endeavour as a solution towards the construction of African theology, which may have global relevance.

1.For more on the origins and background of the African theology, see Tienou (1990) 


\section{Definition and differentiation of African theology}

The quest for a definitive African theology only became an academic concern arguably in the late 1950s and the 1960s (Bujo 1992:5). In the foreword to Bujo's (1992:5) African Theology in Its Social Context, Schreiter particularly posits that the publication of a volume in 1956 by a group of young African theologians in French titled Les Pretres noirs s'interrogent actually marked the beginning of modern African theology. Bujo (1992:2) expands further by pointing out that the first individual African theologian is Mulago who wrote in 1955 and published in 1956, followed by Kagame (1956) and then a group of Africans referred to by Schreiter who published as a group in 1956. What remains obvious here is that published African theological reflections by Africans are a fairly recent effort. The conceptual framework behind the reflections that led to the emergence of African theology as Nkansah-Obrempong (2007:140-141) argues is twofold, namely: African personality in Anglophone Africa and the Negritude movement of Francophone Africa. ${ }^{2}$ In Nkansah-Obrempong's (2007) view, these concepts functioned as tools of regaining identity and:

They also motivated theologians to begin to reinterpret the Christian faith in terms that reflect this identity, so [that] Africans can understand and relate to the Christian faith as their own. These cultural and socio-political movements laid the foundation for African theology of indigenization or inculturation that sees the African culture and religion as important sources for theological reflection on the Christian faith. At the same period in the southern Africa region, the black movement contributed to Black theology of liberation. (pp. 140-141)

These proceedings, according to Nkansah-Obrempong, gave birth to the two major streams of African theologies of inculturation (or contextualisation) and liberation. Inculturation or contextualisation is defined as the effort to take seriously the specific context of each human group and person on its own terms and in all its dimensions - cultural, religious, social, political, and economic and to discern what the gospel says to people in that context, so that the particular needs and hopes of people are addressed and met (Mashau \& Fredericks 2008:119).

The establishment of the Ecumenical Association of Third World Theologians (EATWOT) ${ }^{3}$ in 1976 (in Dares-Salaam) is considered to be a significant marker in the African theological quest. $^{4}$ Before EATWOT, leading African theologians maintained that the existing theology of the African church at the time was 'prefabricated' (Idowu 1965:22-23) and actually

2.Nkansah-Obrempong (2007) defines Negritude as an anti-colonial literary and political movement from the 1930s, expressing pride in being African and black people.

3.Ecumenical Association of Third World Theologians, henceforth EATWOT, refers to an association formed to create a platform for theological reflections by people of Latin America, Africa and Asia.

4.It is worth noting that the formation of the Association of Evangelicals in Africa (AEM) in 1966 preceded the formation of EATWOT in 1976. Though EATWOT is broader ecumenical body, AEM was the first organised body of the Evangelical movement in Africa; and as Nkansah-Obrempong (2010:294) notes, as of today, AEM considers itself as a custodian of evangelical theology or orthodoxy and AEM considers itself as a custodian of evan
upholding Christian values and ethos in Africa. non-existent (Mbiti 1969:232). This assertion, as Bediako (2004:15) maintains, was unmindful of the already existing African theology at the grass roots level. A further reflection by Mbiti (1986:229) decades later acknowledges and confirms the existence of not only written African theology but also oral theology ahead of definitive written theology in Africa. Mashau and Fredericks (2008:10) clarify this point further by maintaining that there is such a thing as lived theologies and academically developed theologies, and it goes without question that the existence of lived theologies in Africa goes as far back as the advent of Christianity in the continent. While Mashau and Frederic's observation could be right, the implication however is that if there was any lived theology before the advent of Christianity, it remains questionable whether such a theology could be termed or equated with Christian theology in the sense of biblical Christianity.

Mbiti (1976:164), therefore, simply defines African theology as the theological reflection by African Christians. Taking his thought further however, if theology is generally understood as reflection and discourse about God, African theology then is that theological endeavour which is embarked upon mostly by Africans and non-Africans who are familiar with the African milieu, and who are seeking to respond to such issues theologically. ${ }^{5}$ This definition recognises that there are nonAfricans who have made significant contributions to the growth and shape of the African theology, either directly or indirectly through stimulating constructive thinking, which fed into the African theology. ${ }^{6}$ Even though the African theology is said to have emerged, what remains unclear and debatable is whether the methodology can be said to be exclusively African (Mashau \& Frederiks 2008:115). Questions remain as to how totally African such a methodology for doing African theology entails. ${ }^{7}$ This is not to infer that there have been no efforts towards a methodology that is African. Nyamiti's (2005) recent two-volume work on methods attests to this.

The concept of 'African theology' cannot be assumed to refer to African Christian theology exclusively. This can be stated in the light of other African theologies that are not essentially Christian. This raises the question as to what constitutes an African Christian theology. As Mugambi (1989:vi-x) demonstrates, without such a differentiation, 'African theology' could generally refer to such theological reflection and discourse as was carried out by Africans before 5.Tiénou (1990:74) agrees with the difficulty that exists in defining African theology.

6.Mbogu (2012:32) addresses the 'insider/outsider' question with regard to African theology and maintains that the foreigner brings with him to the task of African theology his feelings, perceptions, experience and privilege which no matter how small, could distort theology in the other context. However, he admits that to ignore or deny the contributions of outsiders to the development of African theology could amount to academic dishonesty. See also Parratt (1995:19) who makes a strong case for the contribution of non-African contribution to the development of African theology.

7.See Kwesi (in Parratt 1995:20), who discusses the presence and possibility of a Western 'methodological straight jacket' that could hamper originality of thought in African theology. Tiénou (1991:76) had earlier expressed doubt as to whether there African theology. Tienou (1991:76) had earlier expressed doubt as to whether there was yet a fully emerged African theology by stating that, 'genuine African Christian theology is still in the future tense'. He attributes that to the fact that the status of theological education in the continent may contribute, in no small way, to the foreignness of the theological enterprise. Even though Tiénou's position as expressed here was formulated not less than two decades ago, it does not seem to have totally lost its validity. 
the advent of both Christianity and Islam to the continent. In his view, 'African theology' without distinction could imply African Christian or Muslim theology or even a theology of the African religious tradition that is neither Christian nor Muslim. The differentiator therefore that distinguishes African Christian theology is that it is a reflection and discourse that seeks to relate the African cultural and religious heritage to Christianity. Nyende (2005a:3) rightly clarifies further that African Christian theology is 'a theology derived from the interplay of Christian tradition, or any aspect of it, on the one hand, and African cosmology or any aspect of it on the other'. Furthermore, Nyende contends that the Bible is central to a theology that seeks to be Christian and 'it is incumbent on those who wish to articulate an African theology to use the Bible in dialogue with African cosmologies and culture for it to be a Christian theology'. We can concur with this observation when we consider the goal and purpose of African Christian theology, which can be summarised as 'the building and sustenance of African Christian communities in faith, ethos and cultus' (Nyende 2005:3-4).

\section{Context and task of African Christian theology}

In an incisive analysis of the context and development of African theological thought, Bediako (1997:426-443) points out that the context out of which African theology came forth is twofold. In his view, the struggle for the social and political transformation of the conditions of inequality and oppression in South Africa gave rise to 'Black theology', which, in his view, is a theology of liberation in the African setting. On the other hand, the theological explorations into the indigenous cultures of the African peoples gave rise to a different theological strand designated as 'African theology'. Though Bediako maintains that 'Black theology' and 'African theology' are not mutually exclusive, ${ }^{8}$ what he concedes is that they are not one and the same thing. Bediako's differentiation serves to clear the tendency that may exist to wrongly assume that the African theological endeavour is one and the same with the liberationist Black theology. ${ }^{9}$

In concurrence with Bediako, Balcomb (2008:7-10) further sheds light on the contextual and evangelical nature of African theology by maintaining that the Southern African axis, 'south of Limpopo' as he calls it, have had to deal with issues of democratisation and politics with getting rid of apartheid and transformation of the society as a chief goal, thereby leading to the 'theology of bread', while their counterparts in sub-Saharan Africa have had to deal with issues of culture and identity as a chief concern leading to their focusing on the 'theology of being'.$^{10}$ Balcomb (2008:7-10) contends further that what characterises and serves as the

8. Bediako (1997:426), following Desmond Tutu, describes how Black and African theologies relate as 'a series of concentric circles of which Black theology is the inner and smaller circle'.

9.Mashau and Frederiks (2008) identify people at the forefront of Black Theology to include Manas Buthelezi, Gabriel Setiloane, Desmond Tutu, Frank Chikane etc., and note that:African theology that emphasised liberation was typified as 'Black note that:African theology that emphasised liberation was typified as 'Black
Theology', though in recent years also other forms of African liberation theologies Theology', though in recent years also other forms of African liberation theologies
have developed such as African women's theologies and theologies of reconstruction (p. 119).

10.Balcomb in using this expression utilises West (2000). distinguishing features of African evangelical theology ${ }^{11}$ are the nature of its faith, its orthodoxy in relation to foundational doctrines of the Christian faith and its countenance of the powers. He describes faith here not in a soteriological sense or in terms of adherence to the rubrics of a particular church tradition but rather as 'the propensity to believe' primarily in God and also belief in unseen spiritual realities. Such belief in unseen spiritual realities, which, according to him, have been long lost in the west through 'secularisation', enables African evangelical theology to engage such issues theologically.

Balcomb's (2008:7-10) categorisation could have highlighted some exceptions and has succumbed to some generalisation, as he also admits. In fact, one may choose to argue differently about what constitutes an evangelical African theology. Some even debate whether such further categorisation of African theology in terms of 'evangelical' and 'nonevangelical' is even necessary at all. For example, while Parratt (1997:x) shows approval and welcomes the involvement of 'conservative evangelicals' in addressing issues that give shape to African theology and leading to the publication of the African Journal of Evangelical Theology, he, however, deplores extending such categorisations to 'conservative' and 'liberal' which are terms commonly used for categorisation in the West. In his view, such categorisation is unhelpful to the church in Africa. Beyond the question of mere categorisation, our view is that the crucial need for commitment to the essentials of the Christian faith and biblical orthodoxy cannot be overemphasised in the African theological endeavour.

However, Balcomb's analysis in any case gives at least a fair view of what basically underlies the contextual basis of African theology. Furthermore, his pointing out of the distinguishing mark of African evangelical theology as commitment to essential orthodoxy in relation to the foundational doctrines of the Christian faith is important. Its importance lies in going hand in hand with the need to maintain the requisite nature of the Bible for a distinctive and authentic African Christian theology, regardless of whether such a theological endeavour is labelled evangelical or not. This view is buttressed by Nyende (2005:5) who maintains that the place of the Bible as normative and serving as the criterion for what is authentically Christian compels all theologies that would wish to be considered Christian, African theology inclusive, inevitably to come under its scrutiny for validation as Christian theology. This view is not unaware that there are varying opinions and ongoing discussion on the place, the authority and the use of the Bible in African theology (West \& Dube 2000). Considering the above, this article maintains the position that the centrality of the Bible in the African Christian theological endeavour should be sacrosanct. This is not to silence other variables in the task of African theology, but as noted at the beginning of this article, it is an emphasis on the interplay between Scripture, Christian tradition and African cosmology, with the focus being on the Scripture.

11.For a historical background of Evangelical theology in Africa, see NkansahObrempong (2010). 
The task of African Christian theology has been described as understanding Christian theology within the African context and shaping Christian theology within the African world view (Balcomb 2008:8). This, however, does not impinge on the vitality and usefulness of such theological reflection beyond the geographical space of such African theologians. This should be the case especially where heed is paid to Bediako (1997:432), who maintains that African theology should bear in mind an overall goal of making specifically African contributions to the theology of the universal church. The significance of the task of African Christian theology becomes more heightened in the face of the spread of Christianity in Africa along with the attendant need to remain faithful to the essentials of the Christian faith. Hastings' (1976) observation, which was made many decades ago, thus holds true today when he notes that the challenge faced by the African church is not that of decline (as obtained in the West). Rather, the challenges of the African church:

arise instead from the sheer rapidity of growth, from an almost discordant vitality, from the need and often too the determination to reshape the pattern of Church life and thought learnt from European missionaries, directly or indirectly, to accord with the complex religious and secular needs of African society, while remaining faithful to the essentials of Christian tradition. (p. 16)

This observation being the case in present-day Africa makes the task of African theology very pertinent as a vehicle for contributing to the needs of the African society and shaping the church life through engaging issues from a theological and biblical perspective. African theology in its task must keep, as an important goal, the creation of possibilities for the gospel to answer questions raised in the interior of the African world view while removing 'Western hegemonic structures' to enable a response to the gospel that is indigenous (Ogbu 2008:11). Given the considered discussion in this section, African Christian theology refers to a theology that holds to essential orthodoxy in relation to the foundational doctrines of the Christian faith. Having established the meaning of African Christian theology, its context and task in the preceding discussions, the approaching section would present African Christology as a leading subset of African theology (Bediako 1983:110; Mashau \& Fredrick 2008:109; Mbiti 1971:190; Oborji 2008:16; Tiénou 1990:74).

\section{African Christology: Its basis and methodological approaches \\ African Christology: From the margin to the centre of African thought}

Taylor (1963:16), who lived and worked in Uganda, raised the question of the relationship between Christ and African Christians, which stimulated intense thought and Christological reflection among African theologians. Taylor (1963:16) notes that the underlying question in the African Church is the following: 'If Christ was to appear as the answer to the questions that Africans are asking what would he look like?' His question has maintained relevance ever since.
In Banda's (2005:2-6) and Potgieter and Magezi's (2016:1-9) view, this question has received relevance because of the perceived foreignness of Christ in African Christianity that stems from the way some early Western missionaries have presented the gospel from a predominantly Western perspective that results in some Africans' view of Christ as unrelated to them. The question further maintains relevance because of the conceptual novelty about the person and place of Christ in African religiosity. That is, Africans are familiar with God; however, Christ is an unfamiliar concept (Hood 1990:145; Potgieter \& Magezi 2016:3-4). The newness of Christ in African religiosity was worsened by the emergence of Christ with the early Western missionaries that presented Christ as a Western saviour interested in the world views and problems that arise from the Western world (Banda 2005:5; Potgieter \& Magezi 2016:4-5, cf. Taylor 1963:16). This problem was further intensified by the traditional African world view that requires a blood-related ancestor to meet the African contextual needs of African people (Bediako 2004:23; Lugira 2009:48-50; Nyamiti 2006:3, 9; Oladosu 2012:160-116). Given the aforementioned reasons, it is apparent that many African people are not cognisant of how the Christ that the church preaches addresses their existential challenges arises from their traditional African world view(s) (Bediako 2004:23; Pobee 1979:81; Potgieter \& Magezi 2016:2-5; Reed \& Mtukwa 2010:158-161). ${ }^{12}$

As a result of the foregoing Christological challenges, the ancestral Christological approach surfaces as the predominant African Christological approach that is followed by many African theologians (Oborji 2008:16; Wacheche 2012:27). It is an approach that seeks to completely identify Christ with African Christians by treating Christ under the category of ancestor. For example, Bediako (1994:93-121), Bujo (1992:79), Nyamiti (2006:24), Pobee (1979:94), Milingo (1984:85), Kwesi (1984:197-198), Kabasele (1991:123-124) and others are approaching the subject of Christology from an ancestral perspective. The designation of the ancestral category on Christ has gained popularity in academic literature because it addresses the African traditional world view of ancestral veneration, which occupies a central place in traditional African religion (Magezi \& Magezi 2017:2). However, the treatment of Christ under the category of ancestor has been widely challenged by scholars such as Mkole (2000:1138), Reed and Mtukwa (2010:157), Palmer (2008:71) and Potgieter and Magezi (2016:6-7). In different ways, these scholars acknowledge that the treatment of Christ under the category of ancestor takes the traditional African world view seriously; however, it reveals a tendency to diminish the reality of 'Christ as God incarnate and to encourage syncretism in African Christianity' (Potgieter \& Magezi 2016:6-7). Regardless of the challenges associated with the designation of Christ under the ancestral category, we recognise that Taylor's (1963:16, cf. Appiah-Kubi 1987;

12. However, for a detailed discussion on the basis for Africans viewing Christ as unrelated or foreign to them, one should visit Potgieter and Magezi's (2016:1-9) (2016:1-9) article titled 'A critical assessment of Bediako's incarnational Christological mode a a response to the foreignness of Christ in African Christianity'. This article gives missionary presentation of the gospel from predominantly Western perspective, the ancestral worldview and the newness of Christ in African religiosity. These aspects have been explored in detail; hence, there is no need to discuss them in detail here. 
Obaje 1992:47-48; Udoh 1988:162) concern that African theologians too (at least at the time he wrote) are not sufficiently responding to such a crucial Christological question asked by their fellow Africans is addressed by contemporary African theologians.

That is, in the African theological space, the critical nature and importance of the need for clarity on the question of Jesus' identity have been variously expressed by many scholars. The engagement of the aforementioned scholars in the proposed subject suggest that they concur with Mbiti's (1971:190) earlier observation that theology falls or stands on how it understands, translates and interprets Jesus Christ in a given time, place or human situation, and therefore, Christian theology ought to be Christology (Mbiti 1971:190). In a similar vein, Bediako (1983), also a prominent African theologian, comments that:

the heart of the encounter of the Good News with our context is Christology; the significance of our faith in Jesus Christ, crucified and risen for our existence in the world. (p. 110)

In other words, whereas an engagement with the subject matter of Christology was deemed to have failed to generate considerable interest among scholars between 1960 leading up the early 1980s, ${ }^{13}$ this concern as expressed by Bediako (1983:110), Taylor (1963:16), Mbiti (1971:190), Appiah-Kubi (1987), Obaje (1992:47-48) and Udoh (1988:162) led to a vibrant engagement of African theologians with the subject matter of Christology in African theological scholarship in modern times. Noticeable changes in the present scheme of affairs directed Oborji (2008:16) to assert that Christology at present is perhaps the one aspect of African theology that has received the greatest attention from African theologians. This assertion is similar to a position earlier referred to by Nyamiti (1998:17) who maintained that, 'there is no doubt that Christology is the subject which has been most developed in today's African theology'. Perhaps, by 'developed', Nyamiti would be right if he is referring to the fact that there is a widescale engagement with the theme by African scholars at present, causing it to have some shape, as opposed to its former shapeless and almost non-existent form, in which case African Christology can now be considered 'developed'. This is different from being 'developed' in the sense of completeness without the need for further development. What all of this goes to show as Akper (2007:225) notes is that Christology, which was once at the margins of the African theological discourse, now occupies a central position in contemporary African theology. With this in mind, a meticulous examination of the African Christology methods and approaches is the next and necessary step in the following section.

\section{African Christology: Method and approaches Method of inculturation}

Nyamiti (1998:17-39) identifies African theology of inculturation and African liberation theologies as the two

13.De Jongh (1996:2) rightly observes that prior to 1970, a glance at available literature revealed that very little existed in the form of written Christology by African theologians. broad bases undergirding approaches adopted by theologians towards Christologising in Africa. In his view, while those from within the African theology of inculturation make an effort to incarnate the Gospel message in the African cultures on a theological level, those from within the liberation perspective make an effort to find Christ in the socio-political situation of the Africans. As he further points out, among inculturation theologians, there are those whose starting point is the biblical teaching about Christ, after which they proceed to find relevant Christological themes from within the African cultural situation; as well as those within the inculturation subset who take the African cultural background as their point of departure for Christological elaboration.

Some African theologians, such as Bediako, take Scripture as their point of departure. Olsen (1997:258) perceives Bediako's ancestral incarnational Christological concept as grounded in Scripture because he understands that in elaborating on Christology, one has 'to be faithful to Jesus and the witness of the Gospels and the Apostles'. This seems to be evident in Bediako's (1994:99, 2000:24) critique of John Pobee, his contemporary and a fellow leading Ghanaian theologian who also challenges the traditional African ancestral worldview, seeing Christ as the Great Ancestor. In his critique, Bediako maintained that in contextualising Jesus among the Akan people, Pobee 'approached the problem largely through Akan wisdom sayings and proverbs'; thus, 'he does not deal sufficiently with the religious nature of the question'. In this way, Bediako argues that Pobee did not allow the biblical revelation to have a real encounter with the Akan traditional world view of ancestral veneration (Bediako 1994:99, 2000:24). Wendland (1995:113-114) agrees with Olsen in his classical evaluation of current contributions in African Christologies; hence he rates Bediako's ancestral Christology highly as 'the best presentation of a context-sensitive Christology', which is grounded in the Scripture. However, although Bediako seems to have commenced his ancestral incarnational Christology on the basis of the Scripture, it is unclear whether he fully remains within the biblical framework (Wagenaar 1999:373). This means that Bediako's methodological framework is problematic, as he appears to follow the Evangelical doctrine of Christ's incarnation, yet introduces Jesus Christ in African cultural trappings (by treating Christ under the category of ancestor), thus deviating himself from the biblical concept of Christ as one being with God, the Father, as opposed to ancestors.

In view of the methodological approach that starts from the African cultural background to scripture, Wanamaker (1997:282) helpfully points out that this approach which employs 'African cultural background' as the point of departure for Christological elaboration in African theology is 'far more commonly employed' than the method that starts from the biblical teaching about Christ. This fact is evident in the ancestor Christology concept which Nyamiti (1998:17-39), Bujo (1992:79), Pobee (1979), Wanamaker (1997:282) and others subscribe to. These African theologians use the African context as their point of departure for their ancestral 
Christology. This implies that these African theologians are using the African traditional beliefs in ancestors as their starting point for their contextualised Christology. The concern to contextualise the Christ event in Africa is a shared one between African theology and African Christology, and so is the methodology that utilises the culture as a point of departure. Wanamaker (1997) sees validity in such a method by drawing attention to the fact that the early followers of Jesus:

those who shared his human existence and became witnesses to his resurrection, began the process of Christological elaboration by interpreting Jesus in terms of the worldview and themes derived from their own cultural experience. (p. 282)

This methodological approach in doing theology is referred by Mashau and Frederiks (2008:116) as the reverse hermeneutic method' as described below.

\section{The reverse hermeneutical method}

Mashau and Frederiks (2008:116) maintain that an identifiable characteristic in the method of doing theology in Africa and other situations of contextual theologies can be termed as 'reversed hermeneutics'. This involves the reversal of the hermeneutical cycle in which case the hermeneutical movement is from the cultural context to the biblical text instead of the other way around. This approach, which focuses on the context, is also known as contextualisation, and in their contention, this methodology that moves from the African contexts to the text has become the distinctive marker for African theology.

Although 'reversed hermeneutics' as explained above cannot be said to be the only method African theologians have utilised in engaging the biblical text, its prevalence cannot be overstated. To assert that 'reverse hermeneutics' is prevalent and evident in African theology on the other hand confirms that Africans are taking their context seriously and are making efforts to respond theologically to Christological questions that they are faced with. However, the importance of biblical exegesis as foundational for methodology and approach in African theology cannot be overemphasised, as Nkansah-Obrempong (2007) rightly observes. According to him, for African theology to yield any lasting fruit for the community of faith, there is the need to:

make full use of biblical scholarship - sound biblical exegesis and sound cultural exegesis of the contemporary culture in constructing a relevant theology and a theology that will not be sterile and bankrupt. (p. 143)

He adds that creative dialogue between African culture and biblical culture must be ongoing. Further appealing to the African proverb that says, 'wisdom is not found in one person's head', Nkansah-Obrempong (2007:143) insists that African theology needs to consider the teachings of the wider Christian community and also to learn from the traditions of the Christian faith developed over centuries of Christian history. We conclude together with Tiénou's (1990:76) bold assertion that the 'correctness of indigenous African theologies should be judged by the degree to which they are faithful to the Christian Scripture'. According to him, that will make African theologies to have the same reference point as any other Christian theology. He further posits that:

If we maintain the double concern of relating the totality of biblical revelation to the totality of the situation of African Christians, African theology will truly become a discipline at the service of the church. It will cease being either a footnote on Western theology or an instance of exotic Christian religious product for musicologists interested in Africa.

\section{Conclusion}

In conclusion, African Christian theology as a subject should endeavour to develop theologies that go beyond the African continent. That is, African theology should bear in mind an overall goal of making specifically African contributions to the theology of the universal church. The significance of the task of African Christian theology becomes more heightened in the face of the spread of Christianity in Africa, along with the attendant need to remain faithful to the essentials of the Christian faith. The methodological approach of African theology that commences from African cultural context takes the traditional African culture and worldview seriously; however, there is a need for African theologians to continue to embrace Scripture as the authoritative Word of God, thereby making it central and allowing it to govern the contextualisation endeavour. Ancestral Christology serves as one of the predominant subsets of African theology and Christology that is not well received by the popular Christians and academics because it has a tendency of diminishing the reality of Christ as God incarnate and encouraging syncretism in African Christianity. This serves as an example for African theologians to pay close attention to Scripture as their point of departure in doing African theology, and this can possibly result in African theology contributing to the universal church while paying attention to its African contextual needs. Although we are aware of the challenges associated with the task of doing African theology, we conclude that the centrality of the Bible in the African Christian theological endeavour should not be sacrificed.

\section{Acknowledgements Competing interests}

The authors declare that they have no financial or personal relationships which may have inappropriately influenced them in writing this article.

\section{Authors' contributions}

C.M. and J.T.I. equally contributed to the research and writing of this article.

\section{References}

Akper, G., 2007, 'The person of Jesus Christ in contemporary African Christological discourse', Religion \& Theology 14(3/4), 224-243. https://doi.org/10.1163/10230 8012X13397496507388

Appiah-Kubi, K., 1987 (1997), 'Christology', in J. Parratt (ed.), A reader in African Christian theology, pp. 69-81, SPCK, London. 
Balcomb, O., 2008, 'African theology: Contextual \& evangelical', in W.A. Dyrness \& V.M. Karkkainenn (eds.), Global dictionary of theology: A resource for the worldwide church, pp. 7-10, IVP Academic, Downers Grove, IL

Banda, C., 2005, 'The sufficiency of Christ in Africa: A Christological challenge from African traditional religion', MA dissertation, Faculty of Theology, University of South Africa, Pretoria.

Bediako, K., 1983, 'Biblical Christologies in the context of African traditional religions', in V. Samuel \& C. Sugden (eds.), Sharing Jesus in the two thirds world: Evangelical Christologies from the contexts of poverty, powerlessness, and religious pluralism: The papers of the First Conference of Evangelical Mission Theologians from the Two Thirds World Bangkok, Thailand, March 22-25, 1982, pp. 81-121, W. B. Eerdmans Pub. Co, Grand Rapids, MI.

Bediako, K., 1994, 'Jesus in the African culture: A Ghanaian perspective', in A. Dryrness (ed.), Emerging voices in global Christian theology, pp. 93-121, Zondervan, Grand Rapids, MI.

Bediako, K., 1997, 'African theology', in D. Ford (ed.), 1989, The Modern theologians' pp. 426-444, Basil Blackwell, Cambridge, MA.

Bediako. K., 2000, Jesus in Africa: The Christian gospel in African history and experience, Regnum Africa, Yaounde, Cameroun.

Bediako, K., 2004, Jesus and the gospel in Africa: History and experience, Orbis Books, Maryknoll, NY.

Bujo, B., 1992, African theology in its social context, Orbis Books, Maryknoll, NY.

De Jongh, C., 1996, 'A critical analysis of contemporary developments in Christology in Africa', MA dissertation, Faculty of Theology, University of Stellenbosch, Cape Town.

Fredriks, M.T. \& Mashau, D.T., 2008, 'Coming of age in African theology: The quest for authentic theology in African soil', Exchange 37, 109-123. https://doi.org/ $10.1163 / 157254308 \times 278549$

Hastings, A., 1976, African Christianity: An essay in interpretation, Chapman, London.

Hood, R.E., 1990, Must God remain Greek? Afro cultures and God-talk, Fortress, Minneapolis, MN.

Idowu, E.B., 1965, Towards indigenous church, Oxford University Press, London.

Kabasele, F., 1991, 'Christ as ancestor and elder brother', in R. Schreiter (ed.), Faces of Jesus in Africa, pp. 123-124, Orbis Books, Maryknoll, MO.

Kwesi, D., 1984, Theology in Africa, Orbis Books, Maryknoll, MO.

Lugira, A.M., 2009, World religions: African traditional religion, 3rd edn., Chelsea House Publishers, New York.

Magezi, V. \& Magezi, C., 2017, 'Healing and coping with life within challenges of spiritual insecurity: Juxtaposed consideration of Christ's sinlessness and African ancestors in pastoral guidance', HTS Teologiese Studies/Theological Studies 73(3), a4333. https://doi.org/10.4102/hts.v73i3.4333

Mashau, D. \& Frederiks, M., 2008, 'Coming of age in African theology: The quest for authentic theology in African soil', Exchange 37, 109-123. https://doi.org/ $10.1163 / 157254308 \times 278549$

Mbiti, J.S., 1969, African religions \& philosophy, Praeger, New York

Mbiti, J.S., 1971, New Testament eschatology in an African background: A study of the encounter between New Testament theology and African traditional concepts, Oxford University Press, London.

Mbiti, J.S., 1976, 'Some current concerns of African theology', Expository Times 87/b, 164-168.

Mbiti, J.S., 1986, Bible and theology in African Christianity, Oxford University Press, Nairobi.

Mbogu, N.I., 2012, Jesus in post-missionary Africa: Issues and questions in African contextual Christology, San Press, Enugu.

McGlory, S., 2016, 'African biblical hermeneutics on the threshold? Appraisal and wayforward', Acta Theologica 24, 204-224.

Milingo, E., 1984, The world in between: Christian healing and the struggle for spiritual survival, Orbis Books, Maryknoll, MO.

Mkole, J.C.L., 2000, 'Mark 14:62: Substantial compendium of New Testament Christology', HTS 56(4), 1119-1145.

Mugambi, J.N.K., 1989, African Christian theology: An introduction, Heinemann, Nairobi, Kenya.

Nkansah-Obrempong, J., 2007, 'The contemporary theological situation in Africa: An overview', Evangelical Review of Theology 31, 140-150.
Nkansah-Obrempong, J., 2010, 'Evangelical theology in Africa: Ways, perspectives, and dilemmas', Evangelical Review of Theology 34(4), 293-299.

Nyamiti, C., 1998, 'African Christologies today', in J.N.K. Mugambi \& L. Magesa (eds.), Jesus in African Christianity: Experimentation and diversity in African Christology, pp. 17-39, Acton Publishers, Nairobi, Kenya.

Nyamiti, C., 2005, Jesus Christ, the ancestor of humankind: Methodological and Trinitarian foundations, vol. 1, CUEFA Publications, Nairobi.

Nyamiti, C., 2006, Jesus Christ, the ancestor of humankind: An essay on African Christology, vol. 2, CUEFA Publications, Nairobi.

Nyende, P., 2005a, 'Jesus the greatest ancestor: A typology-based theological interpretation of Hebrews' Christology in Africa', PhD Thesis, University of Edinburgh, Edinburgh.

Nyende, P., 2005b, 'Why bother with Hebrews? An African perspective', The Heythrop Journal 46, 512-524. https://doi.org/10.1111/j.1468-2265.2005.00271.x

Obaje, Y., 1992, 'Theocentric Christology', in J. Pobee (ed.), Exploring Afro-Christology, pp. 43-53, P. Lang, Frankfurt am Main.

Oborji, F.A., 2008, 'African theology, Roman Catholic', in W.A. Dyrness \& V.-M. Kärkkäinen (eds.), Global dictionary of theology: A resource for the worldwide church, pp. 15-20, IVP Academic, Downers Grove, IL.

Ogbu, K., 2008, 'African theology: From world wars to decolonization', in W.A. Dyrness \& V.M. Karkkainenn (eds.), Global dictionary of theology: A resource for the worldwide church, pp. 12-15, IVP Academic, Downers Grove, IL.

Oladosu, O.A., 2012, 'Ancestral veneration in the religious expression of the indigenous Aladura churches', Ogbomoso Journal of Theology 17(2), 159-171.

Olsen, J.H., 1997, 'Contextualised Christology in tropical Africa', Svensk Missionstidskrift 85(3-4), 247-267.

Palmer, T., 2008, 'Jesus Christ: Our ancestor?', Africa Journal of Evangelical Theology 27(1), 65-76.

Parratt, J., 1995, Reinventing Christianity: African theology today, Eerdmans, Grand Rapids, MI.

Parratt, J., 1997, Preface in a reader in African Christian theology, S.P.C.K., London.

Pobee, J.S., 1979, Towards an African theology, Abingdon, Nashville, TN.

Potgieter, R. \& Magezi, C., 2016, 'A critical assessment of Bediako's incarnational Christological model as a response to the foreignness of Christ in African Christianity', In die Skriflig 50(1), a2136. https://doi.org/10.4102/ids.v50i1.2136

Reed, R. \& Mtukwa, G., 2010, 'Christ our ancestor: African Christology and the danger of contextualization', Wesleyan Theological Journal 45(1), 144-163.

Speckman, M., 2016, 'African biblical hermeneutics on the threshold? Appraisal and wayforward', Acta Theologica 36, 204-224.

Taylor, J.V., 1963, The primal vision: Christian presence amid African religion, SCM, London.

Tiénou, T., 1990, 'Indigenous African Christian theologies: The uphill road' International Bulletin of Missionary Research 14(2), 73-77. https://doi.org/ 10.1177/239693939001400208

Udoh, E.B., 1988, Guest christology: An interpretative view of the christological problem in Africa, Peter Lang, Frankfurt am Main.

Wacheche, P., 2012, 'Modern trends in Christianity', MA dissertation, Nairob University, Nairobi.

Wagenaar, H., 1999, 'Theology, identity and the pre-Christian past: A critical analysis of Dr. Bediako's theology from a Frisian perspective', Internationa Review of Mission88(351), 364-380. https://doi.org/10.1111/j.1758-6631.1999. tb00165.x

Wanamaker, C.A., 1997, 'Jesus the ancestor: Reading the story of Jesus from an African Christian perspective', Scriptura 62(3), 281-298.

Wendland, E.R., 1995, 'Recent contributions in African theology: A book review article', Africa Journal of Evangelical Theology 14(2), 113-123.

West, G., 2000, 'Mapping African biblical interpretation: A tentative sketch', in M.W. Dube \& G.O. West (eds.), The Bible in Africa: Trajections, trajectories and trena, p. 35, Brill, Leiden.

West, G., 2008, Biblical hermeneutics in Africa. UKZN Ujama Centre, viewed 05 February 2017, http://www.chora-strangers.org/files/chora/west2008_Parratt. pdf

West, G.O. \& Dube, M.W., 2000, The Bible in Africa: Transactions, trajectories, and trends, Brill, Leiden. 